\title{
Chastisement Between Islamic Sharia and the Jordanian Penal Code
}

\author{
Dr. Kefah Alsouri Dr. Ibtisam Saleh \\ Assistant Professor Amman Arab University, Jordan
}

\begin{abstract}
This study addresses chastisement between Islamic Sharia and the Jordanian Penal Code. The Islamic Sharia recognizes the right of chastising children and the wife within legitimacy controls and restrictions. Under Penal Article 62, the Jordanian legislator provides for chastisement where it is considered as one of justification grounds that implies excluding the act from offence and becomes in the context of legitimacy. Our legislation is based on Islamic Sharia, which is a source of the Jordanian Legal System. In order to fulfil the desired goals of the study, it is necessary to start by identifying the Islamic Sharia position on chastising children and identifying the gradual means for chastising children as well as identifying controls and restrictions. Then we explain the right of chastising children in the Penal Code and its legal conditions to justify chastisement as we identify the position of Jordanian Judiciary on this issue. The study has tackled the chastisement of the wife in Islam and the Penal Code and its restrictions. We have concluded in this study that chastisement in Islamic Sharia and Jordanian Penal Code is restricted by the one who has the right to chastise persons subjected to it, chastisement meaning, and its purposes.
\end{abstract}

Keywords: Chastisement, Justification Ground, Trustee, Desertion.

DOI: $10.7176 / \mathrm{JLPG} / 89-20$

Publication date:September $30^{\text {th }} 2019$

\section{Introduction}

Islam urges to build a family on a solid ground based on affection and stability since the educational process cannot achieve its goals of building a complete human being within a stable family and righteous society unless we use effective educational methods which have proven to be efficient and avoid harmful methods that do not achieve the desired goals. Some children turn out well by preaching, guidance, and softness, while others need further firmness and strictness. The child does not exclude this rule, but he is more responsive than older ones. It is necessary to chastise children to bring them up properly without underestimating or hurting them in order to make them love their families and be good in their society ( Qutb, Muhammad, 189).

Islam calls for establishing marital relationships on affection, mercy, and good cohabitation between spouses. Allah says, "And among His Signs is this, that He created for you mates from among yourselves, that ye may dwell in tranquillity with them, and He has put love and mercy between your (hearts): verily in that are Signs for those who reflect," (Al- Room ,21). Islam urges spouses to understand each other to achieve harmony between them; it also asks the husband in particular to forgive his wife's faults and not to overstate her defects by violence, criticism, and discord, but to look at her good traits. On the other hand, Islam urges the wife to respect her husband and treat him properly because he has rights over his wife based on obedience in righteousness avoiding anything that may harm marital life. If the wife breaks the boundaries of obedience in righteousness and exceeds the limit in dealing with her husband, Islam has given the husband the right to chastising her to preserve marital life and ensure its continuity as he has the guardianship and ward ship. Allah says, "Men are in charge of women by [ the right of] what Allah has given one over the other and what they spend [for maintenance] from their wealth," (An-Nisaa, 34). Therefore, chastisement is refining and reforming human beings by those who have the right of guardianship.

According to Jordanian Penal Code, the right of chastisement is one of justification grounds that implies the lack of legal corpus delict because they are restrictions on the scope of criminalization requiring that the act should return to the scope of legality. They are tangible material causes of a substantive nature that have nothing to do with the perpetrator, where its effect is on the act or abstention. It removes the criminal description and disrupts the provision of the criminalization. This does not require research into the offender's psyche, but it depends on the availability of legally required conditions to allow to compromise the penalty protected social interests. It is noticeable that some justification grounds are based on personal reasons related to the legal right and goodwill to use it and not to exceed its boundaries, including the right of chastisement, the topic of this study.

The Jordanian legislator limits justification grounds in Penal Article 59-62 to four cases: exercising the right, legitimate defence, law implementation or obeying the order of authority, and authorizing law. Upon closer inspection of these Articles, we find that some justification grounds are absolute reasons and some are relative. If all justification grounds have achieved their legal effect, which is the elimination of the illegitimate character and it is becoming lawful, thus, one of the pillars of the crime, i.e., illegality, is void, and, therefore, not subject to criminal or civil liability, and no penalty or other criminal effects are inflicted on the beneficiary, nor shall he be 
liable to compensate for the damage caused. However, it differs within the scope of this legal effect in the absolute grounds of justification for which any person, regardless of his status, can benefit such as the legitimate defence, which can be benefited from all who contributed to the illegitimate act, being an accomplice, partner, interferer, or instigator. However, the relative grounds of justification are determined by the legislator for persons or entities occupying a certain position or attribute, including types of chastisement that parents inflict on their children (Hosni, 1975, 186). Although the legal provision expressly has recognized the chastisement of parents to their children, the criminal jurisprudence believes that this license applies also to chastising of husbands to their wives despite the absence of the provision explicitly. They argue that if analogizing is prohibited in the field of criminalization and punishment, there is nothing to prevent its application to the field of justification rules. The husband's chastisement to his wife can be analogized to the chastisement of parents to their children and in a way recognized by Islamic Sharia as it is a part of the public policy in this field (Almjali, $2009,146)$. This study will address the legitimacy of chastising children and the wife.

\section{Chastisement of Children}

\subsection{Chastisement of Children in Islamic Sharia}

Raising children is the responsibility of their parents. They must raise their children from a young age to abide by the teachings and values of Islam. Allah has ordered parents to raise their children according to The Quran and in Sunnah of the Prophet (PBUH). Allah says, "O ye who believe! Save yourselves and your families from a Fire whose fuel is men and stones, over which are (appointed) angel's stern (and) severe, who flinch not (from executing) the Commands they receive from Allah, but do (precisely) what they are commanded," (Al-Tahrim, 6). It means: O believers, keep yourselves, your spouses, and your children from the Fire of Hell by guiding them to goodness, teaching them the etiquette of the Sharia and The Quran, instilling Islamic morals in them, and raising them rightly. The Prophet (PBUH) also made the responsibility of raising children on their parents. Abdullah Ibn 'Umar (May Allah be pleased with them) reported, "I heard the Messenger of Allah saying, 'All of you are guardians and are responsible for your wards. The ruler is a guardian and responsible for his subjects; the man is a guardian and responsible for his family; the woman is a guardian and is responsible for her husband's house and his offspring; and so all of you are guardians and are responsible for your wards' " [Al-Bukhari and Muslim].

Islam legislates the chastisement of children in the family, and graded chastisement means according to certain restrictions and conditions as follows:

First: Encouraging and Rewarding. Motivate the child to obey Allah's order, and reward him when responding either with a material reward such as gifts and games or a moral one. It was narrated from Al-Nadr ibn Al-Harith, who said, "I heard Ibrahim ibn Adham say, "my father said to me, 'O son, I ask for Hadith, whenever you hear a Hadith and memorize it, you will earn a Dirham, so I ask for a Hadith for that.' " (AlBaghdadi, 66). The reward can be a moral one such as praising the child, hugging, or kissing him.

Second: Hinting. By telling a story about an unknown child who made the same misdeed as the child has made and he got punishment, so we are indirectly hinting to the child that his behaviour is bad and he should not do it again.

Third: Advice and preaching privately and repeating the advice with the repeated misdeed.

The boy who committed the misdeed either will understand the hint and quit his misdeed or does not understand the hint and repeats the misdeed. In this case, we advise him privately, gently, and softly without the presence of any others of his relatives or friends, and then we clarify to him that the repetition of this misdeed leads him to trouble and punishment by his family and Allah Almighty. Finally, we praise the child and emphasize his ability not to return to such a misdeed.

Fourth: Confrontation. After the exhaustion of the previous means and the child continues to commit the same misdeeds, we resort to deprive him of his beloved things such as toys and gifts, watching television, or going out with his friends so that he will feel that committing misdeeds deprives him of beloved things. (UmKalthom, 2012, 95-125).

Fifth: Reprimand and Reluctance to the boy. It is a psychological educational method, expressing dissatisfaction with the child's repeating misdeeds. Reprimanding is various degrees according to the person and according to his misdeed. Some children only need to be blamed and admonished, some only need a signal, and some need harsh speech. (Abu-Mukh, 2003, 42).

Sixth: Beating. The jurists argue that it is permissible to use beating in order to chastise the child if the previous means did not work (Ibn-Najim, 8/394, Ibn Al-Hammam, 5/346). All this is according to restrictions and controls that must be met in the tutor, child, and chastisement means based on the Messenger's Hadith (PBUH), as narrated by Abdullah ibn Amr ibn Al 'As, The Messenger of Allah said, "Command your children to pray when they become seven years old, beat them for it (prayer) when they become ten years old, and arrange their beds (to sleep) separately," (Narrated by Abu-Dawud, Praying Book, Hadith No.495, Hasan Sahih). Because prayer requires a reading The Quran, it teaches them the moral values contained in The Quran (Um- 
Kolthum, 2012 ,95-125, Shwedh, Abu-Harbid, 2005, 85-90).

Islam legalizes beating the child in the following cases:

1- Exhausting all educational methods that precede beating; jurisprudence authorizes the use of beating if the previous means did not work in chastising the child and stopping him from committing sins or misdeeds.

2- Achieving the educational goal of beating by taking into account the personality of the child and his character and knowing what works and what does not work with him because if beating does not work with the child, there is no justification for using it.

3- If the child exceeds the age of ten, it is not correct to beat him before this age because he is not yet well-aware. The tutor should be a trustworthy model for the child, patient, and forbearing not to get angry quickly. Allah says, "Enjoin prayer on thy people, and be constant therein," (Taha, 132). He should be aware of chastisement means and its gradation. He must use unharmful and suitable chastisement means such as miswak or napkin and so on because the purpose of beating is chastisement and not harming. He also must avoid face and private parts, does not break a bone or injure the flesh, not to scream, abuse, dispraise, or calibrate with others. Beating should not be sequential or painful or raise his hand high when beating because the purpose of beating is as we mentioned before (Um-Kolthum, 2012 ,95-125) (Al'aqad, 529- 530).

Psychologists meet in their theories with the Islamic approach that punishment is legitimate to resort to in the case of the failure of other educational methods such as encouragement, reward, advice, and confrontation in the reduction of illegal behaviour, where many children do not quit their illegal behaviour without punishment (Al-Nmri, 1999).

\subsection{Chastising Children in the Jordanian Penal Code}

The Jordanian Penal Code explicitly recognizes this in Article 62/2/A, and states, "The act permitted by law shall not be considered a crime." Then Paragraph 2 mentions applications to acts permitted by law, stating that law permits: a) The types of chastisement that parents inflict on their children in a manner that does not cause harm according to the general custom. It should be mentioned that this provision according to Amendment of 2011, where the old provision was as follows: "types of chastisement that parents inflict on their children in accordance with general custom." Thus, the Amendment adds that the act of chastisement should not cause any harm to the boy or girl. Accordingly, the legal provision restricts those entitled to chastising, those subject to it, the means of chastisement, and its purpose. The right of chastisement derives from Islamic Sharia.

The right of chastisement will be established for the father or the like if the child breaches the duties imposed on him or disobeys his father. The father has to take care of his children healthily, to secure housing and food, to raise, and educate them properly in accordance with the rules of law, Islamic Sharia, and social values while children have to obey. Thus, the right of chastisement corresponds with the commitment to control. This is confirmed by the Jordanian legislator in the Penal Articles 289-290, where law criminalizes neglecting anyone below the age of fifteen in a way that puts his life in danger or could cause a permanent damage to his health or not provide him with food and clothing and other necessities with the father's ability to afford. The penalty shall be increased if the minor has not completed the age of twelve.

Accordingly, children in chastisement is any person who has not reached the age of fifteen years or reached it and was in the care of his breeder until the age of maturity or until he lives independently.

According to the provision of Article 62 referred to above, the right of chastisement was limited to parents, the legal guardian of the self and legally assigned to care for his son. It is agreed to expand the meaning of "parents" to include mothers, and this was confirmed by the Court of Cassation in a ruling where it has considered the beating of the mother to her son in order to calm his cry and not with the intent to harm him is justified by virtue of Penal Article 62 (Cassation Penalty 7/17 Journal of syndicate p. 413). In another rule, it did not give the brother the right of chastisement to his brothers, so it ruled that the act done by the appellee stabbing his sister with a knife twice, with one of them reaching her chest cavity, is not chastisement as there is no custom that permits such acts for the purpose of chastisement (Cassation Penalty 105/85).

The meaning of "parents" has expanded to include the guardians such as grandfather or uncle or others in the absence of the father because they are considered legitimate guardians according to Islamic Sharia rules, which is a source of the legal system in this field (Al-Mjali, 2009, 147). It also includes the trustee, who is any person other than the guardian taking care of the juvenile or controlling him according to the legislation in force (Article 2 of Juvenile Law 32/2015). Therefore, the guardian or trustee has the right to chastising orphan children as long as the purpose is to amend the child and educate and manage his affairs that he cannot take over for his young age (Mostafa, 175, 1983).

In order to justify the act of chastisement, it must not cause any harm according to the provision of Jordanian Penal Article (62/2/a). Since the term "harm" is general and absolute, and the absolute remains as such, therefore, it should not cause any harm or damage even if it is simple. Some criminal jurists believe that application of the Penal Article 62 raises problems in application because it is not believed that chastisement does not leave any damage and, therefore, it cannot be applied to cases presented in courts (Ahmed, 305, 2012). 
According to the prevailing opinion, beating should not exceed three strokes, and no tool is allowed other than a hand; a stick is not allowed. Beating should not be on dreaded places such as the head, face, and abdomen. Freedom may be restricted provided that it does not involve torture, prohibition of movement, body aches, or deprivation of education (Al-Shazali, 1998, 270).

That is provided in Article 4 of Jordanian Juvenile Law-2014, which states, "Restricting or using force or isolating the juvenile shall be prohibited except in cases where he shows rebellion or violence as need be." This was confirmed by the Court of Cassation in a ruling as it considered the act of attaching the victim, i.e.,the son, with a chain on his neck, hands and legs and tying him to a column fixed to the bathroom floor and putting locks on the chains to tighten them and close the place around him to prevent his rescue, which led to his death, is a crime of intentional killing (Cassation Penalty , 647/97, 1998). It is also required for the act of chastisement to be justified and not to be considered as a crime is that the chastisement means is permitted by the general custom, i.e., a customary dealing in the social milieu. This issue is left to the discretion of the trial judge. The judiciary has determined that the assessment, whether the father has used his right to chastising as defined by law or not, is a matter of substance for the final adjudication of the trial judge. It was ruled that "the chastisement types permitted by law are those inflicted on children by their parents in a way permitted by the general custom, and the use of an iron tool to beat the child on his head and to break his skull's bone is no longer permitted by general customs" (Cassation Penalty 36/8 Journal of the Syndicate, 736, 1978).

Finally, the right of chastisement is restricted by a condition of goodwill, i.e., the purpose of chastisement is to educate, to teach, and to amend. If it is intended for a different purpose such as retaliation, wrongdoing, committing a crime, or simply insulting and humiliating, it becomes illegal, and the assessment of the availability of such a condition is a matter of substance that leaves its discretion to the trial judge according to the facts in each case.

\section{Chastisement of the Wife}

\subsection{Chastisement of the Wife in Islam}

The husband has the right to chastise his wife upon her reaching the rebellion stage. Rebellion is the disobeying of the wife to her husband unjustly. Allah says, "As to those women on whose part ye fear disloyalty and illconduct, admonish them (first), (next), refuse to share their beds, (and last) beat them (lightly); if they return to obedience, seek not against them means (of annoyance), for Allah is Most High, Most Great (34). If ye fear a breach between them, appoint (two) arbiters: one from his family and the other from hers; if they wish for peace, Allah will cause their reconciliation, for Allah hath full knowledge and is acquainted with all things," (Al-Nisa, $35)$.

The Quran grades the means of chastising by husband to his wife; the purpose is to amend the wife's behaviour but not to harm her. It goes as follows:

First: Preach and guide gently and softly by good words and advice, and remind her of his rights and that Allah orders her to obey her husband. It is necessary to choose the right time to advise and guide women (Interpretation of Al-Sha'rawi, Vol.4, 2220-2221).

Second: If the method of preaching and guidance does not work in amending the wife, then he will abandon her. Scholars said that abandonment may be in the bed's place by refusing to share bed with her, and abandonment is only at home without the knowledge of anyone. The Messenger of Allah (PBUH) had been asked, "What right can any wife demand of her husband?" He replied, "You should give her food when you eat, clothe her when you clothe yourself, not to strike her on the face, and not to revile her or separate from her except in the house." [Abu Dawud, 2/244, Hadith 2142, Hasan Sahih]. It may be an abandonment to speak, i.e., to refuse talking with her, (Mawardi, 481). Abandonment in bed is to chastise her psychologically, where the wife used to be with her husband. When he breaks affection with her for a little time, this method may have the greatest impact on her (Abu Mukh, 2003, 43).

Third: Beating. The husband resorts to chastise his rebellious wife by mild beating if the previous means do not work. Scholars have put controls and restrictions on beating that the husband may not exceed to make beating an efficient means for the return of the wife to her senses and not to be a reason for more disobedience and rebellion. If the husband resorts to chastise his wife by beating, he must take into account gradation in the chastisement means, where the husband should exhaust the previous means of preaching and abandonment. If she does not amend herself and the husband is forced to use beating to chastise her, he must make sure that this method does amend her. If the husband is more likely to think that his wife does not leave disobedience by beating, then he must not beat her at all because it is a useless method in this case. If he chastises her with one stroke, he may not use more. He should avoid beating the face and places that cause harm to the wife. Beating should be mild and does not leave an impact on her body. Some scholars have said that beating should not be more than three strokes because the purpose of beating is chastisement and not harm (Kuwaiti Jurisprudence Encyclopaedia, Vol.10, 23-24). The Messenger of Allah (PBUH) said, "And indeed I order you to be good to women, for they are but captives with you over whom you have no power more than that, except if they come 
with a manifest Fahishah (evil behaviour). If they do that, then abandon their beds and beat them without harming them," (Sunan Ibn-Majah, 1\594, Hadith Hasan).

\subsection{Chastisement of the Wife in the Jordanian Penal Code}

Referring to the Jordanian Penal Article 62/2 addressing the permitting of law, it does not explicitly mention the chastisement of the wife, but it only refers to chastise children by parents. This has provoked a jurisprudential dispute where the modern jurisprudential trend holds that the husband does not have the right to chastise his wife for lack of provision and it is not permissible to analogize the chastisement of a wife to the right of chastising children because analogy in penalties is forbidden (Al-Jbour, 2012, 175).

While another jurisprudence view is the contrary, and it believes that the husband has the right to chastise his wife due to two arguments. Firstly, the Islamic Sharia is part of the Public Legal System in the Hashemite Kingdom of Jordan since the Jordanian Constitution in Article 2 provides that "Islam is the religion of the country", and Article 14 provides that "the country protects the freedom of religious observance in accordance with established customs provided that it is not detrimental to public order or morals." Therefore, since the right of chastisement is established under the provisions of Islamic Sharia, the husband's chastisement to his wife is justified although it is not explicitly stated. Secondly, the exercise of the right as a ground of justification does not necessate that its source must be Penal Code, but it is enough that the right exists legally, i.e., recognized by any legal rule, whether written or unwritten (Al-Qhwajji, 2002, 267).

As it has previously been mentioned, the right of chastisement for the husband is not absolute with no restrictions, but it is restricted by the husband, chastisement means, and its purpose. According to Islamic Sharia, it is not permissible to beat the wife until we exhaust all means of amendment. Beating is not an end in itself, but it is a means to amendment, and if the husband thinks that the wife does not fix her behaviour except by severe beating, it is not permissible to use beating at all. Otherwise, beating will be transformed from being a means to an end in itself, and this is not permissible for the husband (Shadily, 1998, 267).

There are cases that do not justify the husband to chastise his wife, including the breakdown of marital life based on a ruling: there is no right of chastisement in the absence of mutual respect between the spouses and the breakdown of marital life (Iraqi Cassation Penalty, 1964/6/9).

From the foregoing, we find that the right of chastisement according to the previous restrictions permits the husband's acts. If the husband breaks these restrictions, whether because of the lack of reason for chastisement, or exceeding restrictions provided by law for the means of chastisement, or he has a bad intention and abuses the right to chastisement to achieve illegal purposes, his acts shall not be regarded as a use of a right, but rather as a component of a crime for which he is responsible according to his criminal purpose. Therefore, the husband is held responsible for the felony of beating to death according to Penal Article 330 if the husband beats his wife on the head leading to her death intentionally, but if the excess occurs unintentionally, the husband's liability is unintended, and he is questioned for unintended killing in accordance with Penal Article 343.

The question that arises is this: Does the right of chastisement produce its effects as soon as it is available without looking at the knowledge of the perpetrator or should it be known to the perpetrator to entail its effects?

The Jordanian Penal Code is devoid of a provision that resolves this issue, so it is up to jurisprudence and the judiciary to decide. The prevailing view in the jurisprudence believes that if the reason of permissibility has a purely substantive nature, the decisive thing is its existence even if the accused person ignores it such as legitimate defence. However, if the reason of permissibility includes a personal element of an intent or motive, the absence of this personal element necessarily means the absence of the reason of permissibility. Since the personal element presupposes knowledge of the facts underlying the reason of permissibility, the absence of such knowledge, i.e., the ignorance of the availability of other conditions of permissibility means necessarily the absence of the reason for permissibility without taking advantage of it. For example, the right to chastisement presupposes the "intention of chastisement", which requires that whoever uses this right is aware of the act that requires chastisement. Accordingly, if the father beats his son, without knowing his wrong act, he does not benefit from permissibility even if it is proven that the son had done what requires chastisement because the intention of chastisement does not exist based on this ignorance (Najib, 1998, 103-104).

\section{Results}

1. The reason for permitting the right of chastising children and the wife is the goodness of the family, which is the foundation of society. Therefore, to justify chastisement, it must achieve its end.

2. Chastisement is restricted by Islamic Sharia and the Jordanian Penal Code in terms of the one who has the right to chastise, the means, purpose, and who are subject to it.

3. chastisement in Islamic Sharia does not mean resorting to beating directly, but there are graded ways that Islam uses for children and the wife when they misbehave.

4. The requirement of the Jordanian legislator that the act of chastisement should not cause harm or damage will create problems in many cases if not in all of them. Any act of chastisement is not in conceivable without harm 
or damage even if it is a minor harm.

\section{References}

- The Holy Quran.

- Ibn Najim, Zainuddin Ibn Ibrahim, The Clear Sea: Explanation of the Treasure of Facts, the House of Islamic Book, Vol. 8/394/.

- Ibn Majah, Muhammad bin Yazid al-Qazwini (deceased 273 AH), Sunan Ibn Majah, investigation by Muhammad Fouad Abdul Baqi, House of Revival of Arabic books, Faisal Issa al-Babi Halabi.

- Abu Dawood, Suleiman ibn al-Ash'ath (deceased 275 AH), Sunan Abu Dawood, Muhammad Mohiuddin Abdul Hamid, Modern Library, Sidon, Lebanon.

- Abu Mukh, Hanan, The Provisions of Chastisement for Punishment in Islamic Sharia, Master Thesis, An-Najah University, Palestine, 2003.

- Um. Kalthoum, Ben Yahia, Beating Children for Chastisement between Necessity and Harm, Doctorate study, Psychological, Legal, Journal of Truth, University of Adrar, Issue 20, March 2012, pp. 95-125.

- Ansari, Zakaria bin Muhammad bin Ahmed bin Zakaria (deceased 926 AH), The Curriculum of Students in the Jurisprudence of Imam Shafi'i, Edition 1417 AH - 1997 AD). The investigator: Salah bin Muhammad bin Owaida, House of Academic Books, Beirut.

- Al-Bukhari, Muhammad bin Ismail Abu Abdullah, The Whole Musnad Correct Abbreviation of the Matters of the Messenger of Allah (PBUH) and His Sunnah and His Days = Sahih Al-Bukhari, ed. 1, 1422 AH. Investigator: Muhammad Zuhair bin Nasser Al-Nasser, Dar Safety Collar.

- Baghdadi, Abu Bakr Ahmed al-Khatib (deceased $463 \mathrm{AH}$ ), The Honour of the Owners of the Hadith. Investigator: D. Mehmet Said Khattioglu, House of Revival of the Sunnah, Ankara.

- Hosni, Mahmoud Nageeb Hosni (1988). The General Theory of Criminal Intent: A Comparative and Ancillary Study of the Moral Pillar of Intentional Crimes, ed.3.House of Alnahda Alarabya, Cairo, 1988.

- Sha'rawi, Muhammad Metwally, Tafsir Sha'rawi: Thoughts (deceased 1418 AH), Akhbar al-Youm Press.

- Shuwaydih, Ahmad Diab, Abu Harbeed, and Atef Muhammad, Child Chastisement Using Punishment in Islamic Jurisprudence, Islamic University, 2005.

- Abdul Rahman Tawfiq Ahmad, Explanation of the Penal Code, Dar Al Thaqafa for Publishing and Distribution, Amman, 2012.

- Akkad, Abbas Mahmoud, The Quran and Humans, Dar Al-Kitab Al-Arabi, ed. 4, 529 and beyond.

- Ali Abdul Qader Al-Qahwaji, Explanation of the Penal Code, Halabi Legal Publications, Beirut, 2002.

- Fattouh Abdullah Al-Shazly, Penal Code, University Press, Alexandria, 1998

- Qutub, Muhammad, Curriculum of Islamic Education, ed. 16, Dar Al-Shorouk, Vol.1, p. 189.

- Kamel Al-Saeed, Explanation of General Provisions in the Penal Code, House of Al-Thaqafa for Publishing and Distribution, Amman, 2009.

- Muhammad Odeh Jabour, Mediator in the Penal Code, Wael Publishing House, Amman, 2012.

- Mahmoud Najib Hosni, Explanation of the Lebanese Penal Code, General Section, Beirut, 1975.

- Muslim, Ibn al-Hajjaj Abu al-Hasan al-Nisaburi (deceased 261 AH), The Correct Short Musnad Transfer of Justice from Justice to the Messenger of Allah (PBUH), Investigated by Muhammad Fouad Abdel Baqi, House of Revival of Arab Heritage, Academic Library, Beirut.

- Tawfiq Majali, Explanation of the Penal Code / General Section, House of Culture for Publication and Distribution, 2009.

- Nimri, Omar, Reward and Punishment in Education, Al-Bayan Magazine, No. 137, Muharram 1420.

- Ministry of Awqaf and Islamic Affairs, Kuwait I 2 (1404-1427), printed by the Ministry.

- Ibn al-Hammam, Kamal al-Din bin Abdul Wahid, Fath al-Qadeer, Dar al-Kutub, 5/346.

- https://www.wikieef.com/how-to-punish-in-islam/ 